\title{
TRADE LIBERALIZATION: THEORY, PREDICTING THE CONSEQUENCES OF IMPLEMENTATION AND PRACTICAL REALITIES
}

\author{
Марк Хеллаєр, \\ аспірант, Київський національний торговельно-економічний університет \\ Аиректор компанії "СТА" (Великобританія),
}

\section{АІБЕРА АІЗАЦІЯ ТОРГІВАІ: ТЕОРІЯ, ПРОГНОЗУВАННЯ НАС ІАКІВ ВПРОВААЖЕННЯ ТА ПРАКТИЧНІ РЕА $\Lambda$ IÏ}

Background. The competitive positions of countries and their companies largely depend on the nature of participation in international economic interaction. It has been proven that countries with high levels of economic development are benefiting from foreign trade through liberalization. However, it remains debatable how much positive expectations identified in trade liberalization theory can be put into practice in economically peripheral countries.

The fundamental scientific basis for studying the correlation of economic openness in the context of the impact on economic growth, including ambiguous and contradictory impact of trade liberalization, have been studied by various scholars. However, since antagonists of trade liberalization theory often do not fully understand all the positive effects of its application, research in this area is relevant.

The goal of this study is to analyze the development and foundations of trade liberalization theory, as well as to compare projections of the effects of trade liberalization between Ukraine and the EU under the terms of the Deep and Comprehensive Free Trade Area (DCFTA) and the practical realities.

The main results of the research. International trade theory provides explanations for the impact of international trade and the distribution of the gains from trade and particularly trade liberalisation through preferential trade agreements. Classical trade theory supports free trade and advocates against tariffs and restrictions. The assumptions behind the classical trade theory are the following: Completely free trade; no subsidies, tariffs, or commercial restrictions; Frictionless inter-sectoral transfer of labour. However these assumptions do not hold in the real world and gives rise to the debate on the conditions under which free trade provides Gains from Trade.

In the Heckscher-Ohlin model of trade, each nation's comparative advantage is traced to its particular endowments of different factors of production: that is, basic inputs such as land, labour, and capital. Since the costs of these inputs in each country will depend on their availability, differences in factor endowments across countries will create differences in comparative advantage. Each country will tend to export items whose production requires intensive use of the factors with which it is abundantly endowed relative to other nations; conversely, each country will import goods whose production requires intensive use of factors that are relatively scarce. Therefore, countries well endowed with land, like Australia and Canada, and indeed Ukraine, are thus expected to export agricultural products (e.g., wheat and wool), while importing products that require the intensive use of labour (e.g., textiles and footwear).

The article emphasized that Classical theory and Heckscher-Ohlin theory is further developed by the factor price equalization theory, by PaulA. Samuelson. Economic theory of equalization of factors and prices implies that free trade should lead to trends in the equalization of income, capital and labour in different countries. 
The example of graphical models illustrates what to expect in an economy that can move from protection to free trade. It has been shown that this will lead to a net increase in welfare. This made it possible to formulate a scientific understanding of why trade theory supports trade liberalization through preferential trade agreements, such as the DCFTA between the EU and Ukraine. The results of this agreement, as shown by the systematization of short-and long-term expectations, should be to increase trade, more effective allocation of resources, equalise wages and stimulate economic growth. According to forecasts, six sectors in Ukraine were expected to generate additional increases in Exports to the EU of over $20 \%$ net. However, we stressed that Ukrainian business entities will only gain access to the domestic market if European standards are established and technical regulations are complied with. At the same time, the cost of implementation of EU standards and retrofitting of production should be compensated by the flow of European investment which is going to stimulate restructuring and retrofitting of companies, facilitate new businesses and, as the result, increase the state' revenues.

Our personal research has revealed that with 4 years of data since the effective application of DCFTA provisions on Ukraine's exports to the EU, it shows that Ukraine's exports have not significantly improved under the DCFTA. This runs contrary to both the EU and Ukrainian policy objective of the DCFTA as well as traditional economic theory.

Conclusions. According to the traditional economic theory, trade liberalization brings not only traditional "static gains" from specialization, but also the adoption of new technologies and skills, leading to "dynamic gains" from trade - to higher productivity. But in the case of the practical implementation of the DCFTA on Ukraine's exports to the EU, the opposite consequences were found. It is noted that the results obtained during this study can be used for further research towards optimizing the processes of liberalization and upholding national economic interests in the context of the objective growth of world trade. Our data can also be used to find the real reasons that did not allow the country to benefit from the implementation of the DCFTA, as well as to develop measures to eliminate or minimize the negative effects.

Постановка проблеми. Конкурентні позиції країн значною мірою залежать від характеру участі у міжнародній економічній взаємодії. Доведено, що країни з високим рівнем економічного розвитку отримують вигоду від зовнішньої торгівлі шляхом лібералізації. Однак залишається дискусійним, наскільки позитивні очікування, визначені в теорії лібералізації торгівлі, можна реалізувати на практиці в економічно периферійних країнах.

Проблематику впливу економічної відкритості країн на економічне зростання, ут.ч. неоднозначні наслідки лібералізації зовнішньої торгівлі вивчали різні науковці. Проте, оскільки антагоністи теорії лібералізації торгівлі часто не повністю розуміють усі позитивні наслідки її застосування, дослідження у цьому напрямі $є$ актуальними.

Мета цього дослідження - провести аналіз розвитку та ключових положень теорії лібералізації торгівлі, а також зіставити прогнози щодо ефектів лібералізації торгівлі між Україною та ЄС в умовах поглибленої та всеохоплюючої зони вільної торгівлі (ПВЗВТ) та практичні реалії.

Основні результати дослідження. Теорія міжнародної торгівлі дає пояснення впливу міжнародної торгівлі та розподілу прибутку від торгівлі, зокрема лібералізації торгівлі за допомогою пільгових торгових угод. Класична теорія торгівлі підтримує вільну торгівлю і виступає проти тарифів та обмежень. Припущеннями класичної теорії торгівлі є такі: повністю вільна торгівля; відсутність субсидій, тарифів або комерційних обмежень; міжсекторна передача робочої сили без тертя. Однак ці припущення не мають місце в реальному світі і породжуютьдискусію щодо необхідності вільної торгівлі з метою отримання прибуткувід торгівлі.

Проілюстровано, що у моделі торгівлі Хекшера-Оліна порівняльна перевага кожної нації простежується у власних обсягах різних факторів виробництва: тобто основних ресурсів, як-от: земля, праця та капітал, які використовуються в різних пропорціях у виробництві різних товарів та послуги. Оскільки витрати на ці вкладення в кожній країні залежатимуть від їх доступності, відмінності у факторних фондах у різних країнах створюватимуть відмінності в порівняльній перевазі. Кожна країна прагне експортувати товари, виробництво яких вимагає інтенсивного використання факторів, якими вона наділена в порівнянні з іншими країнами; навпаки, кожна країна імпортуватиме товари, виробництво яких потребує інтенсивного використання факторів, які є відносно дефіцитними. Тому країни, наділені землею, як-от: Австралія та Канада, і справді Україна, очікують експорту сільськогосподарської продукції (наприклад, пшениці та вовни), 
водночас імпортують продукцію, яка потребує інтенсивного використання робочої сили (наприклад, текстиль та взуття).

Наголошено, що класична теорія та теорія Хекшера-Оліна були доповнені та розвинені завдяки теорії вирівнювання факторних цін П. Самуельсона. Економічна теорія вирівнювання факторів і цін передбачає, що вільна торгівля повинна привести до тенденцій вирівнювання прибутку, капіталута робочої сили в різних країнах.

На прикладі графічних моделей проілюстровано, на що варто очікувати в економіці, яка може перейти від захистудо вільної торгівлі - до чистого приросту добробуту. Це дало змогу сформолювати наукове поснення того, чому теорія торгівлі підтримує лібералізацію торгівлі за допомогою пільгових торгових угод, як-от: ПВЗВТ між ЄС та Україною. Як свідчить проведена систематизація коротко- та довгострокових очікувань, результатом цієї угоди має стати збільшення торгівлі, ефективніший розподіл ресурсів, вирівнювання заробітної плати та стимулювання економічного зростання. Наведено прогнози, відповідно до яких шість секторів економіки України вже у короткостроковому періоді мали обумовити додаткове збільшення експортудо ЄС на понад 20\%. Водночас наголошено, що українські суб'єкти господарювання отримають доступ до внутрішнього ринку ЄС, якщо будуть встановлені європейські стандарти та дотримані технічні регламенти. Водночас витрати на впровадження стандартів $Є С$ та переоснащення виробництва повинні компенсуватися потоком європейських інвестицій, які будуть стимулювати реструктуризацію та модернізацію компаній, сприяти новому бізнесута, як результат, збільшувати доходи держави.

За даними власних досліджень було виявлено, що протягом чотирьох років з моменту ефективного застосування положень ПВЗВТ щодо експорту України до ЄС, експорт України не суттєво покращився в рамках ПВЗВТ. Останнє суперечить як політичній цілі ЄС, так і українській політиці ПВЗВТ, а також традиційній економічній теорії.

Висновки та перспективи подальших досліджень. Згідно з традиційною економічною теорією лібералізація торгівлі повинна приносити країнам не лише традиційні "статичні вигоди" від спеціалізації, але й "динамічні" через прийняття нових технологій та розвиток нових навичок, що обумовлюють підвищення продуктивності. Проте у випадку запровадження ПВЗВТ щодо експорту України до ЄС були виявлені наслідки, що суперечать теорії. Зазначено, що результати, отримані в ході цього дослідження, можуть бути використані для подальших наукових пошуків у напрямі оптимізації процесів лібералізації та відстоювання національних економічних інтересів в умовах об'єктивного зростання світової торгівлі. Це також може стати підгрунттям для подальшого пошуку реальних причин, які не дозволяють країні отримати вигоди від ПВЗВТ, а також розробки заходів щодо їх усунення або мінімізації негативних наслідків.

Key words: trade liberalization, the Deep and Comprehensive Free Trade Area, economic growth, tariffs, exports, preferential trade agreements.

Ключові слова: лібералізація торгіВлі, поглиблена та Всеохоплююча зона Вільної торгіВлі, економічне зростання, тарифри, експорт, пільговіторговельні угоди.

\section{BACKGROUND}

At all stages of economic development, the state has used and continues to use measures of trade policy to ensure a balance between the interests of national producers and global market development trends. The competitive positions of countries and their companies largely depend on the nature of participation in international economic interaction.

Research findings on the impact of the external component on economic growth suggest that the positive impact of foreign trade and its liberalization on economic growth is currently dominant. Discussions on foreign trade liberalization tendencies are part of the problem, which has a contradictory impact on the economic development of free cross-border movement of goods, capital and labor.

It has been proven that countries with high levels of economic development are benefiting from foreign trade through liberalization. However, it remains debatable how much positive expectations identified in trade liberalization theory can be put into practice in economically peripheral countries.

\section{ANALYSIS OF RECENT RESEARCH AND PUBLICATIONS}

The fundamental scientific basis for studying the correlation of economic openness in the context of the impact on economic growth is the publications of such scientists as M. Clemens, J. Williamson [1], D. Dollar, A. Kraay [2; 3], S. Edwards [4], J. Sachs and A. Warner [5] and others. The consequences of foreign trade liberalization, including ambiguous and contradictory ones, have been analyzed in the publications of E. Choudri, D. Hakura [6], G. Duhinets, V. Tronko [7], J. Francois, M. Manchin [8], J. Nugent [9], D. Rodrick [10] and others [11-16]. 
The antagonists of trade liberalization theory, in our view, often do not fully understand all the positive consequences of putting it into practice. At the same time, in practice, entrepreneurs may not be aware of how they can reap the benefits of trade liberalization. Therefore, the issues of clear coverage of the principles of liberalization and growth theory, as well as the study of various aspects of the application of trade liberalization in practice, are relevant today.

The goal of our study is to analyze the development and foundations of trade liberalization theory, as well as to compare projections of the effects of trade liberalization between Ukraine and the EU under the terms of the Deep and Comprehensive Free Trade Area (DCFTA) and practical realities.

To achieve this goal, we will use the following methods: comparison, systematization, induction and deduction, critical analysis, modeling, etc. Information base of the research is scientific publications, results of own observations and researches.

\section{THE MAIN RESULTS OF THE RESEARCH}

International trade theory provides explanations for the impact of international trade and the distribution of the gains from trade and particularly trade liberalisation through preferential trade agreements.

Classical trade theory [17] supports free trade and advocates against tariffs and restrictions. Free trade is defined as the exchange in international markets that is not regulated or restricted by government actions. Classical theory asserts that there will be benefit and a net gain from international trade. According to the Ricardian models the gains from trade result through the optimum uses of available resources so that the national output is greater, and this raises the level of social welfare (static gains). The assumptions behind the classical trade theory are (i) Completely free trade; (ii) no subsidies, tariffs, or commercial restrictions; (iii) Frictionless intersectoral transfer of labour, that labour can move from sector to another interchangeably. However these assumptions do not hold in the real world and gives rise to the debate on the need for free trade in order to obtain Gains from Trade.

Accordingly, moving from a closed economy to free trade (which can result from preferential trade agreements) produce substantial economic gains because trading countries benefit from specialisation and more efficient resource allocation. In addition, many believe that trade not only brings these traditional "static gains" from specialization, but also the adoption of new technologies and skills, leading to higher productivity - the so-called "dynamic gains" from trade.

Classical Trade Theory therefore favours free, or freer trade, and advocates against tariffs and restrictions. Classical Theory purports that principles of gains from trade and that the overall benefit of trade is positive. According to the Ricardian models the gains from trade result through the optimum uses of available resources so that the national output is greater, and this raises the level of social welfare (static gains).

A refinement of Ricardo's basic model is the Heckscher / Ohlin theory [18]. A condition of trade between two countries is that the countries' differ with respect to the availability of the factors of production. They differ if one country, for example, has many machines (capital) but few workers, while another country has a lot of workers but few machines. According to the Heckscher-Ohlin theory, a country specialises in the production of goods that it is particularly suited to produce. Countries in which capital is abundant and workers are few, therefore, specialise in production of goods that, in particular, require capital. Specialisation in production and trade between countries generates, according to this theory, a higher standard-ofliving for the countries involved.

According to Heckscher / Ohlin, the comparative advantages of different countries and the related patterns of trade that go with them can be explained by examining the differences in access to production factors in different countries. That is, countries rich in natural resources export raw materials. Countries with plenty of labour but little capital tend to export labour-intensive goods and import capital-intensive products.

In the Heckscher-Ohlin model of trade, each nation's comparative advantage is traced to its particular endowments of different factors of production: that is, basic inputs such as land, labour, and capital that are used in different proportions in the production of different goods and services. Since the costs of these inputs in each country will depend on their availability, differences in factor endowments across countries will create differences in comparative advantage. Each country will tend to export items whose production requires intensive use of the factors with which it is abundantly endowed relative to other nations; conversely, each country will import goods whose production requires intensive use of factors that are relatively scarce.

Therefore, countries well endowed with land, like Australia and Canada, and indeed Ukraine, are thus expected to export agricultural products (e.g., wheat and wool), while importing products that require the intensive use of labour (e.g., textiles and footwear) from more labour-abundant economies like China and India. This explains whilst advanced economies of Europe, Japan, and the United States, well endowed with capital relative to the rest of the world, export capital-intensive products (e.g. automobiles and pharmaceuticals), while importing labour-intensive goods from less-developed trading partners where supplies of capital are scarce compared to supplies of labour.

The Heckscher-Ohlin theory says that two countries trade goods with each other (and thereby achieve greater economic welfare), if the following assumptions hold:

- The major factors of production, namely labour and capital, are not available in the same proportion in both countries.

- The two goods produced either require relatively more capital or relatively more labour.

- Labour and capital do not move between the two countries.

- There are no costs associated with transporting the goods between countries.

- The citizens of the two trading countries have the same needs.

Classical theory and Heckscher-Ohlin theory is further developed by the factor price equalization theory, by Paul 


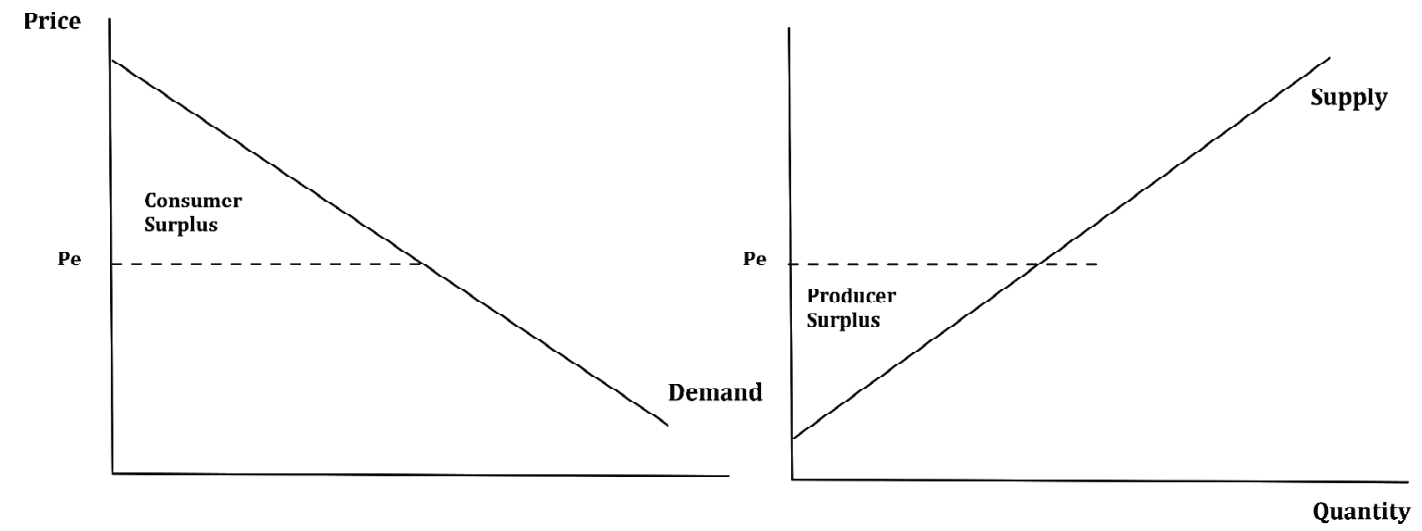

Source: [17; 18].

Fig. 1. Gains from Trade (classical theory)

A. Samuelson [18] which states that the relative prices for two identical factors of production in the same market will eventually equal each other because of competition. The price for each single factor need not become equal, but relative factors will. Whichever factor receives the lowest price before two countries integrate economically and effectively become one market will therefore tend to become more expensive relative to other factors in the economy, while those with the highest price will tend to become cheaper.

An often-cited example of factor price equalization is wages. When two countries enter a free trade agreement, wages for identical jobs in both countries tend to approach each other. After the North American Free Trade Agreement was signed, for instance, unskilled labour wages gradually fell in the United States, and at the same time they gradually rose in Mexico. The same force has applied more recently to the various countries of the European Union during enlargement.

The economic theory of factor-price equalization predicts that free trade should tend to equalize the returns to capital and labour across countries. For example, to the extent that the United States is rich in capital, and relatively lacking in labour power, returns to capital are theorized to be relatively low and returns to labour relatively high, in the absence of trade. (The logic of this is that a scarce factor will command a higher return - higher demand for a factor, relative to available supplies, increases the price that must be paid for it.) Since factor endowments in Bangladesh are the opposite, capital investments there would be expected to receive high returns in the absence of trade, while workers receive low wages compared to those in the U.S.

Once the two countries start to trade, however, the demand for capital in the United States should rise (because the country now has a larger market for selling its capital-intensive goods), increasing the return on investments there. The demand for labour, however, will fall, since the U.S. now imports labour-intensive goods from Bangladesh. Meanwhile, the demand for labour in Bangladesh should rise (because it now exports labourintensive goods), putting upwards pressure on wages in that country, while returns to capital there fall. According to this theory, in a (hypothetical) world of perfectly free trade, we would expect wages to eventually converge, so that workers in the United States and Bangladesh would be paid about the same. Returns to capital investments would also be equalized. The absence of this phenomenon is a result of barriers to trade such tariffs but a free trade agreement will start this equalisation process.

The Stolper-Samuelson theorem then states that trade benefits those who own the factors of production with which the economy is relatively well endowed and trade hurts owners of scarce factors. The reasoning is straightforward: by encouraging specialization in each economy in export-oriented types of production, trade increases the demand for locally abundant factors (and bids up the earnings of those who own those factors), while reducing demand for locally scarce factors (and lowering the earnings of owners of such factors).

The "specific factors" model allows that it can be quite costly to move some factors of production between different sectors in the economy. That is, different types of land, labour skills, and capital equipment often have a very limited or specific use (or range of uses) to which they can be put when it comes to making products. In the specific factors model, the real incomes of different individuals are tied very closely to the fortunes of the particular industries in which they make their living. Individuals employed or invested in export industries benefit from trade according to this model, while those who are attached to import-competing industries are harmed.

In the advanced economies of Europe and the United States, the implication is that owners and employees in export-oriented industries like aerospace, pharmaceuticals, computer software, construction equipment, and financial services, should be much more supportive of trade than their counterparts in, say, the steel, textiles, and footwear industries, which face intense pressure from import competition. There is much evidence supporting these predictions in the real world of trade politics.

The leading research on the political economy of trade now routinely assumes that the specific factors approach is the most appropriate way to think about trade policy preferences, at least in the contemporary context in the advanced economies, but in many historical contexts as well (in which factors of production could not move easily between different sectors within economies).

The demand curve represents the amount of the good that consumers are willing to buy at each price (fig. 1). If the market price turns out to be $\mathrm{Pe}$ the shaded area 


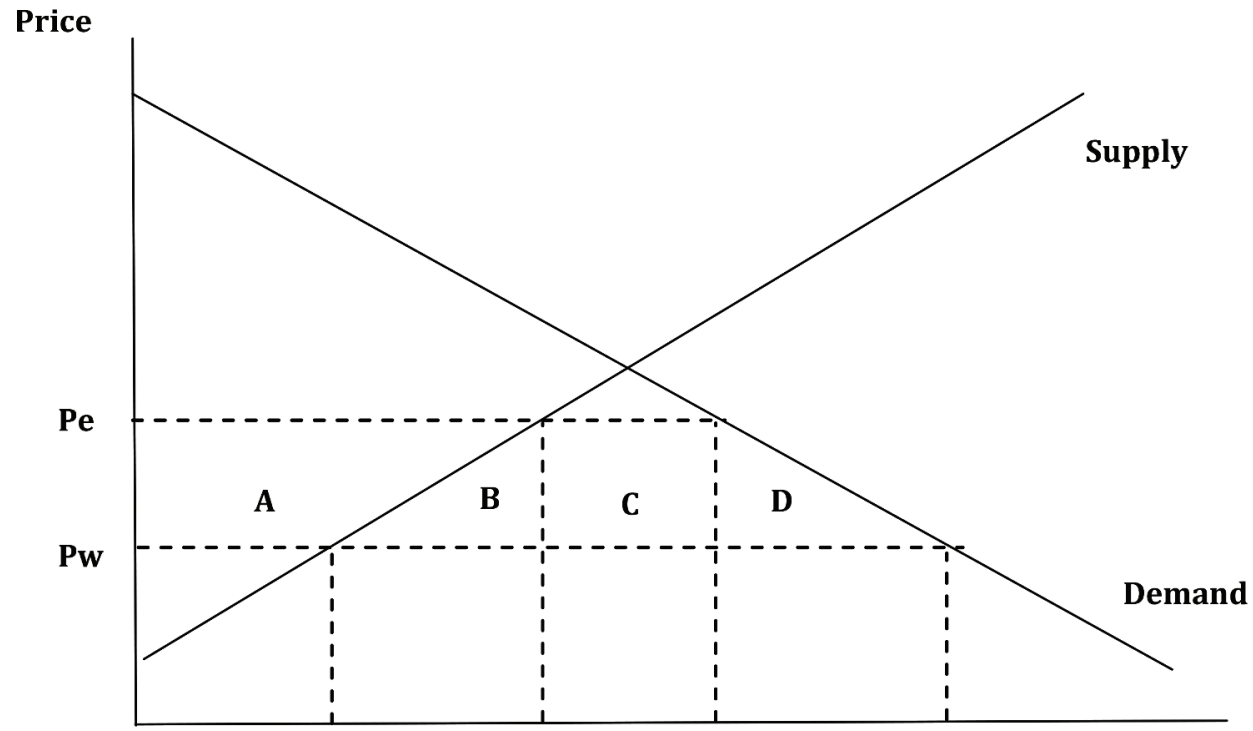

Quantity

Source: [17; 18].

Fig. 2. Benefits of tariff liberalisation *

represents the total "surplus" value that consumers received in buying units of the good at a price below what they were prepared to pay for them.

The supply curve shows the amount producers are willing to supply at each price. If the market price is $\mathrm{Pe}$ the shaded area represents the total value producers received for selling the units of the good at a price higher than the price they were prepared to sell for them. Therefore, trade liberalisation (for example) within a free trade agreement has the following benefit.

Now consider an economy that can shift from protection to free trade. The local market price for the good would fall from $\mathrm{Pe}$ to the world price $\mathrm{Pw}$ (with the removal of a tariff of size $\mathrm{Pe}-\mathrm{Pw}$ ). Local producers lose the amount $A$, government tariff revenues decline by $C$, but total gains from consumers amount to $A+B+C+D$. There is thus a net welfare gain of $B+D$ for the economy. Consumers could compensate producers fully for their lost surplus, and make up the lost government revenues, and there would still be efficiency gains left over.

Trade Theory therefore supports liberalisation of trade through preferential trade agreements such as the DCFTA between the EU and Ukraine. The result of this agreement therefore, should be to increase trade, more effective allocation of resources, equalise wages and stimulate economic growth.

In the case of the Ukraine-EU AA/DCFTA, several authors developed Computable General equilibrium (CGE) models, ex ante to predict the impact and it was in total, expected to have a positive impact on trade as shown in table 1.

In the short term (specified in one study as being within one year of implementation of the agreement), there were a range of predictions on impact of between 1 and $15 \%$ increase in trade due to the AA/DCFTA; that is, averaging predictions, a $7.7 \%$ increase to Ukraine's trade with the EU due to the agreement and in addition to that which would have been expected ceteris paribus, over and above any underlying growth trend.

Many other studies assessing the impact of the AA/ DCFTA also predicted (without quantifying) a positive impact of the AA/DCFTA $[11-14 ; 24-26]$ and others $[15 ; 16]$ simply refer to previous models (mostly Berden et al (2007) [19]) as this was funded by the European Commission) to back up their own qualitative analysis.

The most comprehensive modelling of the predicted sector impact on Ukraine's exports to EU is given in Berden et al (2007) [19]. It details impact based on 3 scenarios: no agreement with EU (called WTO terms but actually means GSP); Scenario 1 with comprehensive tariff coverage and; Scenario 2 with less ambitious agreement. Since the actual agreement between Ukraine and EU is comprehensive, below in table 2 the results of WTO and Scenario 1 are given. To estimate the predicted impact of the AA/DCFTA on specific sectors (net), the WTO terms 
Table 2. Predicted Impact of the Ukraine's Exports to EU by Sector *

\begin{tabular}{|l|l|l|l|}
\hline \multicolumn{1}{|c|}{ Sectors } & $\begin{array}{c}\text { WTO terms } \\
\text { (without } \\
\text { DCFTA) }\end{array}$ & $\begin{array}{c}\text { Short- } \\
\text { term } \\
\text { Impact } \\
\text { (with } \\
\text { DCFTA) }\end{array}$ & $\begin{array}{c}\text { Long-term } \\
\text { Impact } \\
\text { (with } \\
\text { DCFTA) }\end{array}$ \\
\hline $\begin{array}{l}\text { Bovine cattle, sheep and goats, } \\
\text { horse meat products }\end{array}$ & $+21 \%$ & $+33 \%$ & $+34 \%$ \\
\hline Vegetable oils and fats & $+17 \%$ & $+41 \%$ & $+43 \%$ \\
\hline Dairy products & $+9 \%$ & $+20 \%$ & $+21 \%$ \\
\hline Processed rice, Sugar & $+8 \%$ & $+9 \%$ & $+10 \%$ \\
\hline Food products nec & $+7 \%$ & $+28 \%$ & $+29 \%$ \\
\hline Beverages and tobacco & $+6 \%$ & $+12 \%$ & $+13 \%$ \\
\hline Textiles & 0 & $+53 \%$ & $+59 \%$ \\
\hline Wearing apparel & $+35 \%$ & $+273 \%$ & $+288 \%$ \\
\hline Leather products & $+5 \%$ & $+34 \%$ & $+39 \%$ \\
\hline $\begin{array}{l}\text { Wood products, Paper products, } \\
\text { publishing }\end{array}$ & $+13 \%$ & $+31 \%$ & $+34 \%$ \\
\hline Petroleum, coal products & $+3 \%$ & $+20 \%$ & $+22 \%$ \\
\hline Chemical, rubber, plastic products & $+2 \%$ & $+14 \%$ & $+16 \%$ \\
\hline Mineral products nec & +9 & $+53 \%$ & $+53 \%$ \\
\hline Ferrous metals, Metals nec & 0 & $+3 \%$ & $+4 \%$ \\
\hline Metal products & $+2 \%$ & $+11 \%$ & $+12 \%$ \\
\hline Motor vehicles and parts & $+9 \%$ & $+18 \%$ & $+20 \%$ \\
\hline Transport equipment & $+7 \%$ & $+11 \%$ & $+13 \%$ \\
\hline
\end{tabular}

Source: * Composed by the author.

should be subtracted from impact under DCFTA as WTO terms shows the expected impact without the DCFTA.

When considering the sectors that were expected to have the largest impact as a result of the DCFTA preferences, six sectors were expected to generate additional increases in Exports to the EU over $20 \%$ net (short term impact with DCFTA less WTO terms without DCFTA) in the short run:

- Wearing apparel $(238 \%)$;

- Textiles (53\%);

- Mineral products nec $(44 \%)$;

- Leather products $(29 \%)$;

- Vegetable oils and fats (24\%);

- Food products nec $(21 \%)$.

A further 5 sectors were also expected to increase exports to the EU by over $10 \%$ net: wood and paper products; petroleum and coal products; bovine cattle, sheep and goats, horse meat products; chemical, rubber, plastic products and; dairy products.

The long run impact of the DCFTA differed very little from the short term as the models were based largely on price effects on trade resulting from tariff liberalisation and although some tariffs were expected (and actually did) decline over the medium term, most were removed immediately and therefore, most of the impact would be seen only in the short term.

Kravchuk (2016) [23] also modelled the expected increase in exports to the EU under the DCFTA at a sector level stating "only the most competitive industries would thrive" suggesting that the tariff preference effect of the AA/DCFTA would not be significant except in the most competitive sectors which may have increased exports anyway. Kravchuk modelled Ukrainian exports retrospectively and identified crop production (cereals and oilseeds) as having the greatest potential with expected growth of $22 \%$ followed by textiles and clothing at $18 \%$. No further sectors were presented. However, he concludes, "This scenario has already been borne out by the actual impacts of the EU's unilateral market opening to Ukraine in 2014".

Other studies such as Usenko (2007) [25] attempts to assess the impact of the DCFTA on specific sectors such as mechanical engineering, chemicals and light industry but this study simply examines the provisions and theoretical positive and negative effects on respective industries without assessing more closely competitiveness, capacity or any other factors. However, it concludes on balance a positive impact "Ukrainian business entities will gain access to the domestic market if European standards are established and technical regulations are complied with. At the same time, the cost of implementation of EU standards and retrofitting of production should be compensated by the flow of European investment which is going to stimulate restructuring and retrofitting of companies, facilitate new businesses and, as the result, increase revenues to the state budget". Moreover, the analysis and conclusions could apply to any sector and it is unclear why these specific sectors were highlighted.

Our personal research has revealed that with 4 years of data since the effective application of DCFTA provisions on Ukraine's exports to the EU, it shows that Ukraine's exports have not significantly improved under the DCFTA. Average EU imports from Ukraine in 2017 (smoothed 20152017 to take account of annual anomalies) was $€ 13.8$ billion, compared with imports from Ukraine in 2013 (averaged 2011-2013) of $€ 14.1$ billion. This shows that Ukraine's exports are less post DCFTA than pre DCFTA. Moreover, the average rate of smoothed annual growth in EU imports from Ukraine was negative post DCFTA $-0.4 \%$ per annum (20142017) compared with $+10.0 \%$ growth in the same time-period prior to DCFTA (2010-2013).

This runs contrary to both the EU and Ukrainian policy objective of the DCFTA as well as traditional economic theory that states that with the removal of tariffs, trade between the two parties should increase due to specialisation in areas of comparative advantage. It therefore would have been expected that Ukraine's exports to the EU (measured by the EU as imports from Ukraine) should have increased post DCFTA.

\section{CONCLUSIONS}

According to the traditional economic theory, moving from a closed economy to free trade produce substantial economic gains because trading countries benefit from specialisation and more efficient resource allocation. Trade liberalization brings not only traditional "static gains" from specialization, but also the adoption of new technologies and skills, leading to "dynamic gains" from trade - to higher productivity.

Our study shows that in the theory and practice of economically developed countries the transition from protection to free trade can provide a net increase in welfare. This also clarifies why we should support trade liberalization through preferential trade agreements such as EU-Ukraine DCFTA. Forecasts of the positive consequences of trade liberalization between Ukraine and the EU under the DCFTA in the short and long terms also confirm this. But in the case of the practical implementation of the DCFTA on Ukraine's exports to the EU, the opposite 
consequences were found. This runs contrary to traditional economic theory and to both the EU and Ukrainian policy objective of the DCFTA.

We believe that the results obtained during our study can be used for further research towards optimizing the processes of liberalization and upholding national economic interests in the context of the objective growth of world trade. Our data can also be used to find the real reasons that did not allow the country to benefit from the implementation of the DCFTA, as well as to develop measures to eliminate or minimize the negative effects.

\section{References:}

1. Clemens, M.A. and Williamson, J.G. (2001), "A Tariff-growth Paradox? Protection's Impact the World Around 1875-1997", NBER Working Paper, Series, vol.8549, pp.121-132.

2. Dollar, D and Kraay, A., "Is Good for the Poor", [Online], available at: http://ideas.repec.org/p/wbk/ wbrwps/2587.html (Accessed: 20 Oct 2019).

3. Dollar, D. (1992), "Outward-oriented Developing Economies Really Do Grow More Rapidly: Evidence from 95 LDCs, 1976-1985", Economic Development and Cultura Change, vol. 40, pp. 523-544.

4. Edwards, S. (1998), "Openness, Productivity and Growth: What Do We Really Know?", Economic Journal, vol. 108 , pp. 383-398.

5. Sachs, J. and Warner, A. (1995), "Economic Reform and the Process of Global Integration", Broking Papers on Economic Activity, vol. 1, 25th Anniversary Issue, pp. $1-118$.

6. Choudhri, E.U. and Hakura, D.S. (2000), "International Trade and Productivity Growth: Exploring the Sectoral Effects for Developing Countries", [Online], available at: http://www.imf.org/external/pubs/ft/ wp/2000/wp0017.pdf (Accessed: 20 Oct 2019).

7. Duhinets, G.V. and Tronko, V.V. (2015), "Deep and Comprehensive Free Trade Area between Ukraine and EU (DCFTA): realities and prospects", Ekonomichnyj chasopys-XXI [Economic Annals-XXI], vol. 155 (11-12), pp. $10-13$.

8. Francois, J.F. and Manchin, M. (2009), "Economic Impact of a Potential Free Trade Agreement (FTA) between the European Union and the Commonwealth of the Independent States", CASE Network Reports, vol. 84, [Online], available at: http://papers.ssrn.com/sol3/ papers.cfm?abstract_id=1393697 (Accessed: 20 Oct 2019).

9. Nugent, J.B. (2002), "Trade liberalization: Winners and Losers, Success and Failures", [Online], available at http://uoit.ca/sas/International\%20Trade/TradeWinnersLosers.pdf (Accessed: 20 Oct 2019).

10. Rodrik, D. (2001), "Trading in illusions", Foreign Policy, vol. 123, pp. 54-63.

11. Petrov, R. Van der Loo, G. and Van Elsuwege, P. (2015), "The EU-Ukraine Association Agreement: A New Legal Instrument of Integration Without Membership?", Kyiv-Mohyla Law and Politics Journal, [Online], available at: http: / /ekmair.ukma.edu.ua/bitstream/handle / $123456789 / 7874 /$ Petrov_The_EU-Ukraine_Association.pdf? sequence $=5$ (Accessed: 20 Oct 2019 ).

12. Vosta, M. Musiyenko, S. and Abrham, J. (2016), "Ukraine-EU Deep and Comprehensive Free Trade Area as
Part of Eastern Partnership initiative", Journal of International Studies, Vol. 9, No 3, pp. 21-35.

13. Hoekman, B. (2016), Deep and Comprehensive Free Trade Agreements, European University Institute, San Domenico di Fiesole, Italy.

14. Adarov, A. (2016), Trade Effects of DCFTA: Early Results, Challenges and Potential, Vienna Institute for International Economic Studies, Vienna, Austria.

15. Kryvous, V. (2015), "Association Agreement Between Ukraine and EU: Long-Term Opportunities For Cooperation and Risks of Free Trade Area (FTA/DCFTA)", Journal of European Economy, vol. 14, No. 3, pp. $257-$ 267.

16. Adarov, A. and Havlik, P. (2016), Benefits and Costs of DCFTA: Evaluation of the Impact on Georgia, Moldova and Ukraine, The Vienna Institute for International Economic Studies, Bertelsmann Stiftung, Vienna, Austria.

17. Deardorff, A. V. (1980), "The general validity of the law of comparative advantage", Journal of Political Economy, vol. 88, No. 5, pp. 941-957.

18. Feenstra, R. C. (2004), The Heckscher-Ohlin Model. Advanced International Trade: Theory and Evidence, Princeton University Press, UK.

19. Berden, K. G. Smakman, F. and Wymenga, P. (2007), Trade Sustainability Impact Assessment for the FTA between the EU and Ukraine within the Enhanced Agreement, Rotterdam, The Netherlands.

20. Sidenko, V. (2007), "EU-Ukraine Relations in the Context of a Possible Free Trade Agreement", EU Working Papers, vol. 3, pp. 3-18.

21. Movchan, V. and Giucci, R. (2011), Quantitative Assessment of Ukraine's Regional Integration Options: DCFTA with European Union vs. Customs Union with Russia, Belarus and Kazakhstan. German Advisory Group, Institute for Economic Research and Policy Consulting, Berlin/Kyiv, Ukraine.

22. Institute for Economic Research and Policy Consulting (2014), Consequences of the creation of indepth and Comprehensive Free Trade Area between Ukraine and the EU, Institute for Economic Research and Policy Consulting, Kyiv, Ukraine.

23. Kravchuk, A. and Popovych, Z. (2016), The expected impact of the EU-Ukraine Association Agreement, Transnational Institute, Amsterdam; Rosa Luxembourg Stiftung, Brussels; Center of Social and Labor Research, Kiev, Ukraine.

24. Jakubiak, M. Kolesnichenko, A. Boyarchuk, D. Golodniuk, I. Mykhaylychenko, M. Paczynski, W. Tsarenko, A. and Vavryschuk, V. (2006), Prospects for EU-Ukraine Economic Relations, Center for Social and Economic Research, CASE Reports, vol. 66, Warsaw, Poland.

25. Usenko, O. (2007), "Review of the Impact of the Ukraine-EU Free Trade Agreement on Manufacturing Industries (Mechanical Engineering, Chemical and Light Industry)", The Journal of International Economic Policy, vol. 2, pp. $67-100$.

26. Burakovsky, I. Kutsenko, K. Chukhai, H. Kobylyanska, A. Movchan, V. Razdorozhny, Ye. and Sysenko, N. (2010), Costs and Benefits of FTA between Ukraine and the European Union, Institute For Economic Research and Policy Consulting, Kyiv, Ukraine. Стаття надійшла до редакиії 25.10.2019 p. 